\title{
INVISIBLE OLDER PEOPLE: LGBTI+
}

\author{
Naděžda Špatenková \\ Ivana Olecká
}

\begin{abstract}
LGBT older people are an integral part of the ageing population. Due to the unfavourable social climate, they have faced homophobia, discrimination, ostracism, criminalisation, and psychiatrisation for a significant part of their lives; therefore, they remain highly distrustful, wary and reserved to institutions providing social and health services. As a result of years of negative experience, older LGBTI+ people feel very vulnerable and threatened by disrespect of dignity, inappropriate (ill) treatment or even abuse even in these institutions, which is why they hide their identity and sexual orientation. Yet, older LGBTI+ people are clients of both health and social services, as well. However, their situation in health and social institutions has not been adequately dealt with in the Czech socio-cultural environment yet, and older LGBTI+ people are the so-called "invisible minority", "not seen" even by the managers of these facilities, as our research, the results of which we present here, has demonstrated. Setting the quality of services provided and eliminating potential discrimination, however, requires raising the profile of the issue and raising awareness among care professionals.
\end{abstract}

\section{Keywords}

+ LGBTI, older people, care, health care, social welfare, minority, heterosexuality

\section{Introduction}

The senior population is multi-layered and very varied. Non-heterosexually oriented people are an integral part of the ageing older population as well. Previously, the term "homosexuals" or the pejorative term "homos/faggots" were commonly used; later the terms "lesbian", "gay" and "bisexual" prevailed (Hartl, Hartlová, 2010, p. 78). There are also transgender, intersexual, and non-binary people. This wide range of non-heterosexual people is now referred to by the term LGBTI+. The abbreviation refers to lesbians (homosexual women), gays (homosexual men), bisexuals (people 
with a roughly balanced erotic and emotional attachment to persons of both sexes), transgender people (who transcend and break the boundaries between the traditional notions of masculinity and womanhood, such as transsexuals, transvestites, cross-dressers, etc.), intersexuals (people who were born with characteristics not clearly attributable to women or men), and " + " is an expression of the fact that the spectrum of identities is far broader (APA, 1991). There is also an umbrella term "queer" (Demčíšák, 2015; Pitoňák, 2014) or the euphemistic term "rainbow people" referring to the colourfulness and variety of (not only) sex life. The Czech society still lacks enough general knowledge of these terms, not only among the general public, but also professionals.

The exact number of LGBT+ people in the population is very difficult to determine. $4 \%$ of people are said to belong to this category, but the percentage is definitely higher. Ivo Možný (1999, p. 208) states that in the Czech Republic, the estimates of the proportion of persons with homosexual behaviour in the population are around $16 \%$ and $20 \%$ among men and $12-15 \%$ among women. It is clear from the data that this minority is certainly not insignificant, although it is "invisible" to many. Even those who work in social services and healthcare do not "see" older LGBTI+ people. Their situation people will need to be responsibly addressed, because they may need help and care and will certainly not be a marginal group whose values and needs could be ignored. It is also necessary to consider the possible existence of latent homophobia not only among workers in health and social services institutions, but also among other older people in these facilities (Lavrenčíková, 2019). These concerns are based on the historical context of the situation of LGBTI+ people who faced criminal prosecution in what was Czechoslovakia (non-heterosexual orientation was decriminalized in 1961, according to section 244, which, among other things, differentiated the lowest age for same-sex consensual intercourse but was not abolished until 1990; only then was homosexual behaviour judged under criminal law in the same way as heterosexual behaviour), and they were forced into treatment (homosexuality was not excluded from the international classification of diseases until 1993) and discriminated against at work (the prohibition of discrimination in the pursuit of a profession based on sexual orientation has been in effect since 2000) (Novotná a kol., 2016; Weiss, Zvěřina, 2001; Beňová et al. 2007). Experience with criminalisation, stigmatisation, ostracism and psychiatrism made LGBTI+ people hide their sexual orientation, which in turn made them "invisible" to the society as if they did not even exist. Therefore, older LGBTI+ people are still wary and reserved towards others and, above all, distrust institutions. While opinion polls currently confirm a certain tolerance of the majority society towards LGBTI+ people, the experience of non-heterosexual people with discrimination and harassment is three times more common than that of the heterosexual majority. Harassment mostly includes remarks or references to sexual orientation or gender identity (Ombudsman, 2019). According to the Public Opinion Research Centre research (Tuček, 2020), one in four Czech people say they would not want an LGBTI+ person for a neighbour and one in two believes that a person admitting that they are LGBTI+ would cause some trouble in their neighbourhood. In the Czech Republic, the so-called heterosexualism is still an established 
rule and a social norm. Based on heteronormativity, heterosexuality is perceived as the only possible sexual orientation, and minority sexual orientation is considered an aberration, something not normal (Fafejta, 2004, p. 76-77; Beňová et al., 2007, p. 35; Lavrenčiková, 2019, p. 24). Those who fail to comply with heterosexual and gender norms are perceived as "the others". Their otherness is the basis for the emergence of stigmas, prejudice, discrimination, and violence (Institute of Medicine et al., 2011, p. 13). The normalcy of heterosexualism is so strongly rooted in the Czech society that homosexuals are usually considered as people who have "failed" their families by their sexual orientation and family members often break off contact with them. Thus, LGBTI+ people lose any opportunity for informal family help and care when they are ill and socially needy. Even those who tolerate homosexuality see it as something not to be presented in public. Public space does not belong to non-heterosexuals; they have access to it, but only if they behave according to heterosexual norms. In this sense, heterosexualism is a privilege (Fafejta, 2004, p. 80). LGBTI+ people often experience stress stemming from fears about social surroundings' responses to their sexual orientation, the so-called minority stress (Pitoňák, 2017, p. 580; Orel, Fruhauf, 2015). Minority stress can be the cause of the worse psychological and physical state of older LGBTI+ people. King and Richardson (2017, p. 61) mention research (e.g. by Cochran, Sullivan, Mays, 2003; Wright, Owen, Catalan 2012) that proves that older LGBTI+ people who have experienced minority stress suffer from more severe health and mental health problems than heterosexual people. The authors report that older LGBTI+ people exhibit more hazardous behaviour, manifesting, for example, excessive alcohol and substance abuse that enables them "escape" the reality of minority stress. They also suffer from a higher rate of depression, manifested by more frequent thoughts of suicide. Mental health is closely related to physical health. In his presentation created under the auscpices of the National LGBT Health Education Center, Simone-Skidmore (2013) states that LGBT older people suffer from the so-calledweis co-morbidity (multiple concurrent illness). Common chronic diseases include, for example, higher cholesterol, cardiovascular problems, cancer, obesity problems, and frequent occurrences of sexually transmitted diseases, predominantly in gay and bisexual men. The author also points out that the health of transsexual individuals is severely affected by lifelong use of hormones and other medications that support the conversion process. Therefore, it can be assumed that older LGBTI+ people will need help and both health and social care. They may feel vulnerable and threatened by discrimination, disregard for dignity, inappropriate treatment or even abuse as a result of their experience even in health and social services institutions. Therefore, it is imperative to pay close attention to their protection, including especially the protection of their dignity. This is also mentioned in the Article 10) of the Charter of Fundamental Rights and Freedoms: "Everyone has the right to maintain their human dignity, personal honour, good reputation and to protect their name." As the age of the older population becomes higher, the non-sufficiency of older people and their dependence on others increases, and so does the need to place older LGBTI+ people in health and social services facilities as they generally cannot rely on the help 
of their family or informal caregivers. Social contacts of LGBTI+ people tend to be poorer due to the above-mentioned historical context. Discrimination based on sexual orientation and gender identity has led to more limited and fragmented interactions with the biological family. Biological links were replaced by non-family ones, the so-called "family of choice". It includes ex-partners, friends, or work colleagues who support each other and turn to each other in case of illness and need for help (Wenzel, 2015; Novotná et al., 2016, p. 8). Older LGBTI+ people also face a formal disadvantage compared to the majority population, e.g. even though they live in a registered partnership, this does not automatically confer entitlement to the partners' joint assets (assets acquired by an individual during a registered partnership remain either individually owned by one of the partners or shared equally), i.e. not even inheritance rights, let alone the widow/ widower's pension. Negative historical experiences of older LGBTI+ people establish the specificities of this population relative to heterosexual seniors. However, the LGBTI+ community is not united, e.g. older people identifying as transsexual or bisexual are confronted with far greater problems than lesbian and gay people (Novotná a kol., 2016). Many have encountered more rigorous obstacles, e.g. some bisexual individuals say they are ignored and overlooked by the gay and lesbian community and they even describe instances where they are shunned by that community. Based on these experiences, they may feel they have to assume the gay or lesbian identity to be accepted. In terms of violence and harassment, transgender people experience much greater levels of physical and verbal violence (Hash, Rogers, 2013, p. 249-251). These problems become much more serious once these people are physically or psychologically indisposed and no longer able to defend themselves (Baker, Krehely, 2011; Daley et al., 2017).

The situation of LGBT+ older people in the Czech Republic has been outlined in Analýza situace lesbické, gay, bisexuální a transgender menšiny v ČR (The Analysis of the Ssituation of the LGBT Minority; Beňová et al., 2007). In 2016, the authors of this article carried out the Analysis of the Situation of LGBT seniors in Medical and Social Institutions (Novotná a kol., 2016), followed by the following partial survey. Currently, the Government Strategy on Removing Legal and Social Barriers to the Decent and Equal Life of LGBT+ People in the Czech Republic 2021-26 has been established.

\section{Research methodology}

The presented research was based on the following research question: Are providers of care for older people ready to provide services to LGBTI+ people? Due to the nature of the topic, a qualitative research paradigm has been chosen to answer this research question, namely the Interpretative Phenomenological Analysis (IPA), which provides a deep insight into the issue (Smith, 2004, 2007). Its aim is to understand the social situation, the way individuals or groups perceive or experience a situation they are confronted with, and what meaning they attribute to this experience. Through the examination of specific personal experiences, the analysis tries to apprehend events 
or processes - the phenomenons - in the individual's world and the way the individual perceives and understands events, situations, and experiences. This approach allows us to explore even the qualities that cannot be easily quantified.

The research has been carried out among providers of care for older people, with senior managers (directors) of health and social institutions being approached. The aim of this research was to reflect on the experiences of the facilities with LGBTI+ people, and the readiness to take them and in address situations related to LGBTI+ issues. Semistructured talks have been conducted with the managers of these institutions. A total of nine managers have participated in the research, including four health managers (MZ 1-4) and five social managers (MS 1-5) of institutions. All interviews have been recorded on a voice recorder, then verbatim transcribed and subjected to content analysis in accordance with the IPA methodology. A total of 8 categories have been identified.

\section{Survey results}

In analysing narratives, several categories have surfaced; these could be found in all the narratives. Altogether, we have defined five categories:

1. The invisible ("we cannot see them and don't have them")

2. No difference ("we are all human")

3. Heteronormativity as a norm ("to act normal")

4. All older people are somehow the same ("every older person has their own specificities")

5. No problem ("the problem is not the problem; the problem is how it is handled")

6. Regard and respect ("respect in the first place")

7. Ignoring individuality ("it doesn't matter anymore")

8. (No)topicality of the issue ("dementia is in")

\section{The invisible ("we cannot see them and don't have them")}

Managers of health and social institutions point out that they have never had and do not have, such older people in their facilities, confirming the established hypothesis of the population's "invisibility". "We don't have such clients. And if so, we don't know about them." (MS1) "I don't have personal experience with LGBTI+ people, at least not that I know of. We've never dealt with this issue in our care, or I think we haven't dealt with any problem that had to be solved by care staff... when analysing the complaints received, we haven't found any problems with the LGBT issue in our institutions so far." (MZ2) 


\section{No difference ("we are all human")}

The managers questioned strongly agree that there is no need to make a distinction between LGBTI+ and heterosexual people; they think that in terms of both care and access, older LGBT+ people are ordinary clients; they do not reflect any specificities. Therefore, care should be the same and provided with no difference ("we are all human"). "I believe they are ordinary clients. There is no need for special approaches from either a health or social point of view." (MS3) "These are ordinary users of care; there is no need for a special approach in terms of health or social care. An immobile older LGBTI+ person needs the same solution, e.g. barrier-free treatment or mobility equipment (a wheelchair, walker, lift etc.) as any other immobile older person." (MZ3) "Is he ill? He is. And is he LGBTI+? So what? We provide health care based on his condition, not sexual orientation. We're a hospital, not a brothel. We're interested in his illness, not his sexual orientation..." (MZ4) "So what if he's LGBTI+? Am I supposed to take a banner, organize a parade and tell people I'm straight or something? I don't get it; I don't understand it... He's a man like us. So what's the problem?" (MS1) "...we in healthcare put the emphasis on the biological side. You just can't make a difference between people. The Hippocratic Oath is unequivocal, so if someone has lung cancer, it doesn't really matter if they're black, white, yellow, gay or lesbian or, for example, a mother of six. So I don't think there's any difference; care should be the same for everyone. No one should be discriminated against, but even those who live in a marriage as heterosexuals have a lot of children and so on..." (MZ1) "I don't think older LGBTI+ people need special treatment..." (MS4) "He's exactly the same human being as we are." (MS2) "Healthcare is the same for all; a good medic should do the same quality work, whether it's for an LGBTI+ person or anyone else." (MZ3)

\section{Heteronormativity as a norm ("to act normal")}

All the interviewed managers thought the key was the way the older person behaves or would behave, which closely correlates with heteronormativity in the Czech society and institutions providing care (not only) for older people. They believe, for example, that if the older LGBTI+ person would behave much differently, draw attention to themselves or manifest their sexual orientation too much (in their opinion), they might get into some trouble with the other older people (the recipients of care), as well as the workers in the helping professions (the care providers). Non-heterosexual people can be then endangered by intolerance and homophobia. "It depends on their behaviour; it they're radical and tell everyone... There are people who don't hide anything but act quite naturally, so no problem would occur..." (MS3) "It would depend on their behaviour..." (MS5) 


\section{All older people are the same in a different way ("every older person has their own specificities")}

The interviewed managers see no problem in taking older LGBTI+ people in institutions providing health and social care. They see an older LGBTI+ person as every other older person, spontaneously emphasising that "every older person has their own specificities". "Well, God has us all sorts..." (MS5) "There are conflicts among older people because of other things as well..." (MS4) "Problems arise with all older people, for any reason." (MZ1) Institutions providing care for older people always need to approach solving their problems individually. Social and health services as such declare respecting the individuality of each person and accentuate personal comfort of the care recipients. Their (secondary) interest is then to helpfully reconcile the interests of stakeholders (LGBTI+ and other people) to general satisfaction ("everyone has their own specificities"). "After all, we in the social services continuously plan things, prepare individual plans of how we want things and the service work. So, this is not a problem." (MS1) "Social services look more at whether the person is happy or not..." (MS4) "In my practice, I've met several older handicapped LGBTI+ people in residential facilities and haven't seen a problem. Some lived there with their partners." (MS3) "It's always all about the individual, and in terms of health/social care; I believe it's necessary to have an individual approach to every client, whether an LGBT or heterosexual person." (MZ2)

\section{No problem ("the problem is not the problem; the problem is how it is handled")}

The approached managers of institutions providing health and social care believe that professional carers should have no problem with providing care to older LGBTI+ people. The education of future health and social workers adequately reflects the needs and requirements of the older population. At the same time, managers of institutions providing social and health care point out that some education dealing with the issues of LGBTI+ people should be available also to other employees in daily contact with older people, e.g. cleaners. "Caring professionals are encouraged to professionalism and approach without prejudice to all people." (MS4) "Our employees are trained to be able to communicate difficult or challenging situations, but I see no objective reason why care for older LGBTI+ people should be any different (in terms of sexual orientation) from care provided to heterosexual clients. I think communication problems and operationally difficult situations may arise in case of transgender people. Theoretically, I wouldn't expect any problems with lesbians and gays." (MZ2) "We think there are certain reserves, and we lack methodological instructions for working with these clients." (MZ4) "Cleaners are in daily contact with these clients as well; they're with them in their rooms and they all have to treat them with respect." (MS1) "I guess I'd provide some basic information about the older [non-heterosexual] person to the stuff but no special preparation is necessary. Older LGBTI+ people have already worked out their issues; they often live with their 
partners for years. When they have physical pain, they need a doctor like everyone else. When they feel pain in the soul, for example, when they lose their partner, they need psychological care like everyone else. A psychologist should be able to handle this situation professionally, without any special preparation." (MZ3)

\section{Regard and respect ("respect in the first place")}

Participants in our research also agree that it is not practical to establish a special facility exclusively for older LGBTI+ people. Rather than segregate older LGBTI+ people and concentrate them in a special institution of social services, it is appropriate to integrate them and apply the fundamental rule: "Respect for the person as such is crucial regardless of their sexual orientation." "I think that mutual respect, ethical principals, love to your neighbour, even when they're impossible or seem to be impossible, just tolerating them and understanding them is much more urgent than any LGBTI+ issues..." (MZ1) "... mutual respect; I really think mutual respect is a must. And it doesn't matter if the person is young, old, white, black, or gay..." (MS3) "I wouldn't segregate them, really. Soon, someone would come to surround the place with barbed wire... no... that's not... I'm against this; if we just respect each another, they can live among the others, right...?" (MZ3) "Any discrimination or segregation is always wrong..." (MS4) "There are hunchbacked people, too, and we won't place them in a separate centre for the hunchbacked..." (MS1)

\section{Ignoring individuality ("it doesn't matter anymore")}

The interviewed managers are convinced that when older people get into a nursing home or a medical facility, sexual orientation doesn't have a crucial role anymore ("it doesn't matter anymore"). This attitude, however, most likely resonates with prejudices and stereotypes (Tošnerová 2002) or myths about old age, respectively (Haškovcová, 1990, 2010). "You know, it doesn't matter anymore... if the older person is LGBTI+ or whatever... they're simply infirm, dependent, confused... They're simply happy to be alive. This [issue] isn't important then. And they don't care either. When you have dementia, then you really care about nothing..." (MZ1) "When the person is in a hospital or nursing home, they don't feel well at all and cannot even walk... So, it probably doesn't matter anymore... well, I think... at a certain age, it doesn't matter... like in the satirical sketch of [comedians] Šimek and Grosmann, when one of them says: Are you waiting for the doctor, madam? And the other one says: I'm not a madam, I'm a gentleman. And the first one says: It doesn't matter at our age... So, yeah, something like that. At a certain age, it doesn't matter..." (MZ1) "When I feel really bad, I'd lie in a hospital next to a man." (MZ5) "As for nursing homes today, they take in people with the highest care benefits, so that's another thing. These people are basically immobile. We don't have any walking older people here." (MS3) 


\section{(Non-)topicality of the issue ("dementia is in")}

Although none of the respondents considers the topic urgent, they all recognize that this is a subject little discussed and that older LGBT+ people are ultimately "invisible". Therefore, wider awareness nationwide would be extremely useful, mainly to eliminate and minimize the communication barriers. In the past, it was a very taboo subject but even today, it is not dealt with and reflected enough. "Older LGBTI+ people? Well I don't know. Cognitive disorders are a more topical problem. So, rather dementia. An older person with dementia - it doesn't matter if they're LGBTI+ anymore..." (MZ1) "I find this issue topical due to the increasing number of older people, so there probably will be a greater number of older LGBTI+ people, too." (MS5) "Different sexual orientation of older people isn't an issue for me. I don't they think about it anymore. What we have to deal with is dementia... This is an issue! Not whether these people are or aren't LGBTI+." (MZ1) "In my opinion, they're normal clients. In terms of healthcare, LGBTI+ doesn't seem a paramount issue." (MZ2) Even though the participants considered the issue of older LGBTI+ people irrelevant, they pointed out that it was more than likely to be topical in several years. The interviewed managers of health and social institutions estimate it would happen in thirty to forty years. It is possible that future generations will see it differently because ("young people are different"). „It'll be different later on... But not now... nobody would talk about it now. Can you imagine keeping secret from everyone for all your life and, once you grow old, coming to a nursing home saying: I'm gay!? Probably not... It probably won't happen. At least not now. In this generation. But it'll be different for the younger generation... It's quite possible that there even be a nursing home for gay older people. But I can't imagine that now, not really..." (MS3) "Young people see it differently, so it's highly likely that their ideas will be different, but the older generation... I can't imagine that - after so many years when they kept the secret so hard, afraid that someone would find out..." (MZ1)

\section{Discussion}

The principal findings of our research all the participants agree on lie in the fact that so far, no discussion of the situation of older LGBTI+ people has taken place among professionals. The research has shown that managers of health and social institutions see this issue as something new, unexplored. Most of them (like the majority of the society) feel that the situation of LGBT+ people is relevant to younger generations, not to older people. The situation of older LGBTI+ people is not seen as a social problem and it is not addressed by law and/or policies (e.g. by creating a legislative framework or an extension of quality standards). The reasons why this discussion does not take place can be found in the fact that it is a topic marginalized by the professional community, based on prejudices and ethically overly sensitive. The philosophy of care for older people in the Czech Republic and their mentality do play a role as well. However, it should be noted that all the managers interviewed were interested in the subject and admitted they 
had never thought about it before. Only one manager sees the LGBTI+ issues among older people as a socially pressing issue. Clearly, older LGBTI+ people remain "out of sight" for our generation that knows virtually nothing about their problems (Beňová et al., 2007, p. 15). Thus, older LGBTI+ people are exposed to double visibility - not only to the majority population, but also to the LGBTI+ community itself (Novotná a kol., 2016). According to Baker and Krehely (2011, p. 19), invisibility is only one of the consequences of a lifetime of oppression. We must be constantly aware that the current cohort of older LGBTI+ people lived in times when non-heterosexual orientation was considered a psychological illness and sexual behaviour between individuals of the same sex was illegal and immoral (Orel, Fruhauf, 2015, p. 14). "To make oneself invisible" meant to survive; hiding one's minority sexual orientation and gender identity became a necessity. The persistence of social stigmas, prejudice, bias, and legally conditional discrimination has fundamentally affected not only older LGBTI+ people (Baker, Krehely, 2011 , p. 19), but also the attitude to them. Orel and Fruhauf (2015, p. 117) point out that in recent years, public discrimination has often been replaced by an atmosphere of silence. This form of neglect or disregard leads to the marginalisation of older LGBTI+ people and should be seen as part of the discrimination. However, any form of discrimination is very dangerous and should be eliminated.

The topic of LGBTI+ seniors is an unexplored topic. Our research serves as one of the first entries into this sensitive topic. We believe that it would be highly appropriate to expand research efforts to other target groups such as direct care workers, lawyers, social workers and other stakeholders from the professional community in future research efforts. It would also be very interesting to find out the attitudes of the general public.

\section{Conclusion}

Older LGBTI+ people have lived a significant portion of their lives in the times of prevailing social homophobia and heterosexism, which, unfortunately, still affect their experience of ageing. At an older age, the experience of long-term discrimination and stigmatisation is reflected in several important areas (Novotná a kol, 2016, p. 9). The first area is significantly marked by a history of oppression is access to social and health services. Older LGBTI+ people delay not only hospitalisation in health facilities, but also possible entry into a social services institution (Meyer, 2011, p. 24). Meyer (2011, pp. 24-25), Baker and Krehely $(2011$, s. 20) agree that the reason for the postponement is fear of abuse, bias, discrimination, and mistreatment by staff of these institutions. Daley et al. (2017, pp. 145-146) point out that these people may be mistreated not only by workers, but also by other older people and their families who do not want to be in contact with LGBTI+ people. This situation leads in turn to feelings of isolation and loneliness and tends to cause physical and psychological hardship for LGBTI+ people. In this context, the requirement for a community-wide discussion on the topic, as well as specific training for workers in assisting professions to engage with LGBTI+ people, is becoming topical. 


\section{References}

American Psychological Association. Avoiding Heterosexual Bias in Language. American Psychologist, October 1991, 46(9), 973-974. Retrieved from https://www.apa.org/pi/ lgbt/resources/language

Baker, K., \& Krehely, J. (2011). How health care reform will help LGBT elders. Public Policy and Aging Report, 21(3), 19-23.

Beňová, K. et al. (2007). Analýza situace lesbické, gay, bisexuální a transgender menšiny $v$ ČR. Prague: Úřad vlády ČR (The Office of the Government of the Czech Republic).

Cochran, S. D., Sullivan, J. G., \& Mays, V. M. (2003). Prevalence of mental disorders, psychological distress, and mental health services use among lesbian, gay, and bisexual adults in the United States. Journal of Consulting and Clinical Psychology, 71(1), 53-61. Retrieved from https://doi.org/10.1037/0022-006X.71.1.53

Daley, B. (2017). Why LGBT initialism keeps growing. Chicago Tribune, 2.

Demčíšák, J. (2015). Kategória queer a jej analytický potenciál. Trnava: Univerzita sv. Cyrila a Metoda v Trnave.

Fafejta, M. (2004). Úvod do sociologie pohlaví a sexuality. Nakladatelství Jan Piszkiewicz.

Hartl, P., \& Hartlová, H. (2010). Psychologický slovník. Prague: Portál.

Hash, K. M., \& Rogers, A. (2013). Clinical practice with older LGBT clients: Overcoming lifelong stigma through strength and resilience. Clinical Social Work Journal, 41(3), 249257.

Haškovcová, H. (1990). Fenomén stáři. Praha: Panorama.

Haškovcová, H. (2010). Fenomén stáří. Vydání 2., přepracované a doplněné. Praha: Havlíček Brain Team. ISBN 978-80-87109-19-9.

Institute of Medicine, et al. (2011). The Health of Lesbian, Gay, Bisexual, and Transgender People: Building a Foundation for Better Understanding. Washington, D.C.: National Academies Press.

King, S. D., \& Richardson, V. E. (2017). Mental health for older LGBT adults. Annual Review of Gerontology and Geriatrics, 37(1), 59-75. 
Lavrenčíková, D. (2019). "Neviditelní" senioři v sociální službě II. Sociální služby, 21(6-7), 24-26.

Meyer, H. (2011). Safe spaces? The need for LGBT cultural competency in aging services. Public Policy and Aging Report, 21(3), 24-27.

Možný, I. (1999) Sociologie rodiny: její vývoj, teorie a základní problémy. Prague: Karolinum.

Novotná, J., Špatenková, N., Olecká, I., \& Hasmanová Marhánková, J. (2016). LGBT senioři/rky - neviditelná menšina. Situace stárnoucích leseb, gayư, bisexuálních a trans osob v České republice a perspektivy LGBT prátelské zdravotní a sociální péče. Praha: Platforma pro rovnoprávnost, uznání a diverzitu z.s.

Ombudsman Být LGBT+ v Česku. Zkušenosti LGBT+ lidí s predsudky, diskriminací, obtěžováním a násilím z nenávisti. Výzkum veřejného ochránce práv 2019 [online]. 2019. [12. 3. 2016]. Available from: https://www.ochrance.cz/uploads-import/DISKRIMINACE/ Vyzkum/Vyzkum-LGBT.pdf

Orel, N. A., \& Fruhauf, C.A. (2015). The lives of LGBT older adults: Understanding challenges and resilience. Washington: APA.

Pitoňák, M. (2014). Queer prostor(y). In R. Matoušek \& R. Osman. (Eds.), Prostor(y) geografie (123-146). Praha: Karolinum.

Pitoňák, M. (2017). Rozdíly v duševním zdraví mezi ne-heterosexuály a heterosexuály: přehledová studie. Československá psychologie, 61(6), 575-92.

Simone-Skidmore, M. (2013). LGBT Aging: Addressing Disparities and Health Care Needs. Sage.

Smith, J. A. (2004). Reflecting on the development of interpretative phenomenological analysis and its contribution to qualitative research in psychology. Qualitative research in psychology, 1(1) 39-54.

Smith, J.A. \& Osborn, M. (2007). Interpretative Phenomenological Analysis. Qualitative Psychology; 9 (26) 53 and 80 [online]. [7. 6. 2015]. Available from: http://www.sagepub. com/sites/default/files/upm-binaries/17418_04_Smith_2e_Ch_04.pdf

Tošnerová, T. (2002). Ageismus: průvodce stereotypy a mýty o stáří. Praha: Ambulance pro poruchy paměti. 
Tuček, M. (2020). Tolerance k vybraným skupinám obyvatel - březen 2020. Tisková zpráva. Centrum pro výzkum veřejného mínění, Sociologický ústav AV ČR, v.v.i. Microsoft Word - ov200430 (cas.cz) [Cit. 9.11.2016].

Weis, P. \& Zvěřina, J. (2001). Sexuální chování v ČR - situace a trendy. Prague: Portál.

Wenzel, H. V. (2015). Fact Sheet: Legal Issues for LGBT Caregivers. LA: Family Caregiver Alliance.

Wright, R., Owen, G., \& Catalan, J. (2012). I'm older than I ever thought I would be: The lived experiences of ageing in HIV-positive gay men. In R. Ward, I. Rivers, \& M. Sutherland (Eds.), Lesbian, gay, bisexual and transgender ageing: Biographical approaches for inclusive care and support (pp. 85-101). London, United Kingdom: Jessica Kingsley Publishers. Available from: https://www.researchgate.net/publication/330832609_ Mental_health_for_older_LGBT_adults [accessed Jul 27 2021].

\section{Authors}

PhDr. et. Mgr. Naděžda Špatenková, Ph.D., MBA

Faculty of Public Policies in Opava, Silesian University in Opava

Institute of Pedagogical and Psychological Sciences

Bezručovo nám. 885/14, 74601 Opava, Czech Republic

nadezda.spatenkova@fvp.slu.cz

PhDr. et. Mgr. Ivana Olecká, Ph.D.

Department of Christian Social Work, Sts Cyril and Methodius Faculty

of Theology

Palacký University Olomouc

Univerzitní 244/22, 77900 Olomouc, Czech Republic

ivana.olecka@upol.cz 